13. Rabinowitz HK, Becker J, Gregory N, Wender R. NIH funding in family medicine: an analysis of 2003 awards. Ann Fam Med. 2006;4:437-442.

14. Department of Health and Human Services. National Institutes of Health. Computer Retrieval of Information on Scientific Projects (CRISP). Available at: http://crisp.cit.nih.gov/crisp/crisp_query.generate_screen. Accessed: 23 August 2006.

15. Katerndahl D, Crabtree BF. Creating innovative research designs: the 10-year methodological think tank case study. Ann Fam Med. 2006;4:443-449.

16. Thomas P. Primary care professionals need to be aware of the theories on which our work depends. Ann Fam Med. 2006;4:450-454.

17. Stein HF. Family medicine's identity: being generalists in a specialist culture? Ann Fam Med. 2006;4:455-459.

18. Candib LM. Sí, doctora. Ann Fam Med. 2006;4:460-462.

19. Kaufman A, Derksen D, Alfero C, et al. The health commons and care of New Mexico's uninsured. Ann Fam Med. 2006;4(Suppl 1):S21-S26.

20. Schwenk TL, Green LA. The Michigan clinical research collaboratory: following the NIH roadmap to the community. Ann Fam Med. 2006;4(Suppl 1):S41-S46.

21. Magill MK, Lloyd R, Palmer D, Terry S. Successful turnaround of a university owned, community-based, multidisciplinary practice network. Ann Fam Med. 2006;4(Suppl 1):S31-S37.

22. Smith JK, Weaver D. Capturing medical students' idealism. Ann Fam Med. 2006;4(Suppl 1):S50-S55.
23. Berg AO, Norris T. A workforce analysis informing medical school expansion, admissions, support for primary care, curriculum, and research (University of Washington). Ann Fam Med. 2006;4(Suppl 1):S12-S16.

24. Roth P. Managing the uninsured with a community network. Ann Fam Med. 2006;4(Suppl 1):S27-S30.

25. Roper WL, Newton WP. The role of academic health centers in improving health. Ann Fam Med. 2006;4(Suppl 1):S47-S49.

26. Krugman RD. Commentary on Utah primary care experience. Ann Fam Med. 2006;4(SUppl 1):S38-S40.

27. Eckhert NL. Getting the most out of medical students' global health experiences. Ann Fam Med. 2006;4(Suppl 1):S56-S57.

28. Rourke J. Social accountability in theory and practice. Ann Fam Med. 2006;4(Suppl 1):S17-S20.

29. Newton WP, DuBard C. Shaping the future of academic health centers: the potential contributions of departments of family medicine. Ann Fam Med. 2006;4(Suppl 1):S2-S11.

30. Michener JL, Powell DE, Susman JL, et al. Family medicine and the evolution of academic health centers: a dialog with leadership. Ann Fam Med. 2006;4:S58-S60

31. Martin JC, Avant RF, Bowman MA, et al for the Future of Family Medicine Project Leadership Committee. The future of family medicine: a collaborative project of the family medicine community. Ann Fam Med. 2004;2(Suppl 1):S3-S32.

\title{
EDITORIAL
}

\section{Reliving History and Renewing the Health Care Reform Debate}

Katbryn Pitkin Derose, $\mathrm{PbD}, \mathrm{MPH}$

Nicole Lurie, MD, MSPH

RAND Health, Santa Monica, Calif, and Arlington, Va
A s the 2008 presidential elections approach, health care reform is once again easing its way into the consciousness of many Americans. At last count, 48 million of them-nearly one fifth of

Conflicts of interest: none reported

\section{CORRESPONDING AUTHOR}

Kathryn Pitkin Derose, PhD, MPH

RAND Health

1776 Main St

Santa Monica, CA 90401-3208

derose@rand.org those younger than 65 years-lacked health insurance, ${ }^{1}$ and signs abound that the cost of health insurance is now a problem for both the middle class and the nation's economy. The importance of health insurance in obtaining health care and ensuring health has been documented for several decades, as have the effects of going without it. For example, more than 20 years ago, Lurie et $\mathrm{al}^{2,3}$ and Witcher and Fihn ${ }^{4}$ studied populations whose health insurance (Medicaid and Veterans Administration benefits, respectively) were terminated. Both studies documented significant declines in access to care as well as worsened health status, hypertension, and diabetes control. Furthermore, in the Medicaid 
population studied, excess deaths were evident within 6 months of losing insurance, and the estimated risk of dying was increased by $40 \%$.

Since these studies were conducted, evidence has continued to accumulate regarding the profound and lasting effects of uninsurance on health care access and on health outcomes, particularly for populations who are poor or in poor health. Two articles in this issue add further to this body of evidence. Carlson et $\mathrm{l}^{5}$ studied a cohort of adults enrolled and formerly enrolled in the Oregon Health Plan and found that losing coverage had immediate and negative effects on access to care and increased medical debt. Meyers et $\mathrm{al}^{6}$ conducted a pilot study of 25 physicians in a primary care research network in Washington, DC, finding that physicians reported making changes in clinical management of patients based on insurance status. In particular, in nearly one half of visits with uninsured patients, physicians reported a change from their preferred management, whereas such a change occurred only in less than one third (29\%) of those who were publicly insured and one quarter (19\%) of those privately insured $(P=.01)$.

Some thoughtful critics may argue that these findings come as no surprise. Of course, losing health insurance leads to people to seek less care, some of which was probably unnecessary in the first place. Furthermore, physicians, as stewards of society's health care resources, indeed ought to think twice before ordering many tests and treatments. But we assert that deciding not to order tests and treatment should be based on necessity and standards for highquality care rather than because there is no one to pay the bill. Rationing care based on insurance coverage is neither equitable nor an efficient way to discourage unnecessary care, and it tends to put those who need health care the most at a disadvantage. Furthermore, if losing insurance means less primary, preventive, and chronic disease care, the downstream consequences of worse health are likely to create even further inequities and ultimately put additional strain on taxpayers, who, after all, finance the increasingly beleaguered Medicare trust fund.

Despite clear documentation of the perils of uninsurance, cutbacks in Medicaid in response to skyrocketing costs, like those seen in Oregon, are becoming commonplace, as are decisions of employers and individuals to go without health insurance because it is so costly. Unfortunately, these changes come at a time when the medical profession is also particularly challenged. On the one hand, physicians are providing much less charity care now than a decade ago. ${ }^{7}$ On the other hand, in the face of considerable waste, duplication, and overuse, patients receive on aver- age only $55 \%$ of recommended care for prevention, acute illness, and chronic disease ${ }^{8}$ All of these factors-increasing numbers of uninsured, decreasing charity care, and poor-quality health care-suggest that the time is indeed ripe for renewed efforts at health care reform. As the accompanying debate heats up, let us not lose sight of the fact that health insurance, although vitally important, is by no means the only factor affecting access to care and health status. A growing literature on the underlying determinants of health tells us that good health is also dependent on addressing fundamental issues of the social, economic, and physical environments in which we live. As physicians and public health professionals, we can and should do better for our patients and communities than leaving them without either access to care or to the conditions that create good health.

Family medicine as a field has begun to emphasize the importance of engaging in issues regarding health care reform. For example, the Future of Family Medicine's Task Force on Family Medicine's Role in Shaping the Future Health Care Delivery System proposed 6 priorities to foster necessary changes ${ }^{9}$ including the following 3 that specifically address issues related to health care reform and access:

1. Asserting leadership to transform the US health care system by initiating a dialogue on how best to provide integrated care of the whole person

2. Taking steps to ensure that every American has a personal medical home

3. Advocating that every American has health care coverage for basic services and protection against extraordinary health care costs

We applaud this task force and its efforts. Family physicians, as providers of care for people across the lifespan and across all settings, are well situated to contribute in a constructive fashion to reforming the health care system. Although the task force mentions a public health role for family physicians, we think that the profession should go further, joining the discussion about access to care and the health care system with one about access to health and the public health system and its attention to the underlying determinants of health. Only in this manner will both the upstream causes and the downstream consequences of poor health be simultaneously addressed in whatever new system emerges.

The challenges before us are enormous. With increasing numbers of the uninsured and increasing pressures on physicians that compromise their ability to provide timely and effective care, the situation around the country is in many ways worse than 20 years ago. Now, more than ever, we need physicians, in both their medical and public health roles, to join with other 
health and public health professionals to contribute to the upcoming health care reform debate. Debate alone is not enough; this time we must emerge from the debate with actual solutions-solutions in which the twin goals of access to care and access to health are achieved in a way that works not only for payers and physicians, but for patients, families, and communities.

To read or post commentaries in response to this article, see it online at http://www.annfammed.org/cgi/content/full/4/5/388.

Key words: Access to health care; delivery of health care; health services research; health policy

Submitted August 30, 2006; accepted August 31, 2006.

\section{REFERENCES}

1. Agency for Healthcare Research and Quality. The Uninsured in America, 2004: Estimates for the U.S. Civilian Noninstitutionalized Population under Age 65. Available at: http://www.meps.ahrq.gov/ papers/st83/stat83.pdf. Accessed: 28 August 2006.
2. Lurie N, Ward NB, Shapiro MF, Brook RH. Termination from MediCal-does it affect health? N Engl J Med. 1984;311:480-484.

3. Lurie N, Ward NB, Shapiro MF, et al. Termination of MediCal benefits. A follow-up study one year later. N Engl J Med. 1986;314:1266-1268

4. Fihn SD, Wicher JB. Withdrawing routine outpatient medical services: effects on access and health. J Gen Intern Med. 1988;3:356-362.

5. Carlson M, DeVoe J, Wright B. Short-term impacts of coverage loss in a Medicaid population: early results from a prospective cohort study of the Oregon Health Plan. Ann Fam Med. 2006;4:391-398.

6. Meyers D, Mishori R, McCann J, et al. Primary care physicians? Perceptions of the effect of insurance status on clinical decision-making. Ann Fam Med. 2006:4:399-402.

7. Cunningham PJ, May JH. A growing hole in the safety net: physician charity care declines again. Track Rep. 2006:1-4.

8. McGlynn EA, Asch SM, Adams J, et al. The quality of health care delivered to adults in the United States. $N$ Engl J Med. 2003:348:2635-2645.

9. Roberts R, Snape P, Burke K. Task force report 5. Report of the task force on family medicine's role in shaping the future health care delivery system. Ann Fam Med. 2004;2(Suppl 1):S88-S99. 